Resumo de Tese/Thesis

\title{
Transplante de medula óssea alogênico em pacientes portadores de anemia aplástica grave, abaixo de 12 anos de idade, condicionados com ciclofosfamida e irradiação corporal total
} Allogeneic bone marrow transplantation in patients with severe aplastic anemia younger than 12 years old, conditioned with cyclophosphamide and total body irradiation

Roberto L. Silva

Orientador

Frederico L. Dulley

\section{Resumo}

O transplante de medula óssea é o tratamento de escolha para crianças com anemia aplástica grave, que possuem um doador com antígeno leucocitário humano compatível. 0 grande problema com relação a esta terapêutica eram as elevadas taxas de rejeição naqueles pacientes que recebiam o condicionamento clássico só com ciclofosfamida, principalmente entre os politransfundidos no pré-transplante de medula óssea. Com objetivo de reduzir os índices de rejeição, optamos por associar a irradiação corporal total com 300 cGy à ciclofosfamida, na dose de $50 \mathrm{mg} / \mathrm{kg} / \mathrm{dia}$ intravenosa, por quatro dias nas crianças com idade inferior a 12 anos, portadoras de anemia aplástica grave, no período de janeiro de 1991 a dezembro de 2001. Dos 13 pacientes avaliados neste estudo, os resultados obtidos foram os seguintes: taxa de sobrevida livre de doença de $92,3 \%$ em 120 meses; sobrevida global de 84,6\% em 140 meses; toxicidade imediata aceitável relacionada ao tratamento e diminuição no crescimento de quatro crianças, que, no entanto, entraram no estudo já com déficit pré-transplante de medula óssea, impossibilitando a correlação da persistência da baixa estatura com o regime de condicionamento. Redução dos níveis séricos do hormônio de crescimento insulina simile-1, e normalidade dos níveis séricos do hormônio de crescimento e proteína ligadora de hormônio de crescimento insulina simile tipo 3 na maioria dos casos avaliados. A avaliação dos hormônios tireoidianos também foi realizada, não sendo observada nenhuma alteração nos níveis séricos destes pacientes. Em relação à avaliação oftalmológica não se observou catarata em nenhum caso. Avaliou-se também o desenvolvimento sexual, o qual mostrou normalidade dos caracteres sexuais secundários e níveis hormonais. Não houve rejeição nos pacientes estudados.

Abstract

Bone marrow transplantation is the treatment of choice for children with severe aplastic anemia who havea donor compatible in human leukocyte antigen system. The great problem of this therapy is the high rejection rate in patients who received the classic conditioning only with cyclophosphamide, mainly in the polytransfused patients, in the pre-transplant Aiming to reduce the rejection rates, we chose the association of total body irradiation with $300 \mathrm{cGy}$ to cyclophosphamide $50 \mathrm{mg} / \mathrm{kg} / \mathrm{day}$, intraven ous, for four daysin children younger than 12 years old, with severe aplastic anemia, from January 1991 to December 2001. Of the thirteen patients enrolled in this study the findings were: Disease-free survival rate of $92.3 \%$ in 120 months; global survival rate of $84.6 \%$ in 140

Dissertação - Faculdade de Medicina, Universidade de São Paulo, para obten ção do titulo de Mestre em Medicina.

Correspondência para: Roberto Luiz da Silva

Rua Vergueiro, 2.949 - Vila Mariana

CEP: 41120-300 - São Paulo-SP

Tel.: (11) 3061-5544 R. 218,227/ (11) 3069 -53019 (Incor) 
months; the immediate toxicity related to the treatment was minimal and impaired growth of four children. However, these children were already enrolled in our study with deficiency in their height, and it is difficult to prove a correlation with the conditioning regimen. There were reductions of the insulin-likegrowth factors hormone serious level, normalization of the growth hormone and binding of protein-3 in most of the cases studied. The assessment of the thyroid hormones was also carried out and alterations concerning the serious level were not observed. An ophthalmologic assessment was carried out and cataracts was not observed and the assessment concerning the sexual development showed normality of the secondary sexu-

al characteristics and normal hormonal levels as well. There was no rejection in the patien ts evaluated.

Recebido: 04/02/2003

Aceito: $18 / 02 / 2003$ 